\title{
Renal angiomyolipoma during pregnancy: Case report and literature review
}

\author{
Gebelikte renal anjiomyolipom: Olgu sunumu ve literatürün \\ gözden geçirilmesi
}

\author{
Cihan Çetin, Selim Büyükkurt, Cansun Demir, Cüneyt Evrüke \\ Çukurova University Faculty of Medicine, Department of Obstetrics and Gynecology, Adana, Turkey
}

\begin{abstract}
Renal angiomyolipoma is a rare tumor that can be either sporadic or found together with tuberous sclerosis or pulmonary lymphangioleiomyomatosis. These tumors are hormone sensitive and therefore tend to grow during pregnancy and their main complication is the risk of rupture. Optimal management is still controversial because there are very few cases reported in the literature. We expect that the case of our patient, who delivered her baby vaginally at 36 weeks of gestation and underwent definitive treatment (nephrectomy) thereafter, to further enhance the knowledge about the management of these rare tumors during pregnancy. J Turk Soc Obstet Gynecol 2015;2:118-21
\end{abstract}

Key Words: Angiomyolipoma, nephrectomy, pregnancy

\section{Özet}

Renal anjiomyolipom, nadir bir tümördür. Sporadik olabileceği gibi, tüberoz skleroz veya pulmoner lenfanjioleiomyomatozis ile birlikteliği de olabilir. Bu tümörler, hormon duyarlıdır, bu yüzden de gebelikte büyüme eğilimi gösterirler. Bu tümörlerin esas komplikasyonu rüptür riskidir. Optimal yönetimi hala netleşmemiştir, çünkü literatürde bununla ilgili çok az sayıda olgu sunumu vardır. Bu olguların çoğunda da gebelikte rüptür gelişmiş ve hastalar sezaryan ile doğurtulmuştur. Olgumuzun, rüptür olmadan 36. gebelik haftasında vajinal yoldan doğurtularak ve kesin tedavi (nefrektomi) bunu takiben gerçekleştirildiğinden dolayı bu tümörlerin gebelikteki yönetimi konusundaki bilgimizi daha da arttıracağını ummaktayız. J Turk Soc Obstet Gynecol 2015;2:118-21

Anahtar Kelimeler: Anjiomyolipom, nefrektomi, gebelik

\section{Introduction}

Renal angiomyolipoma (RA) are rare tumors with an incidence of $0.3 \%$ in the general population and are even rarer among women who are pregnant $(1)$. These tumors arise from epithelioid cells around blood vessels, can be sporadic, but may also be associated with tuberous sclerosis complex (TSC) or pulmonary lymphangioleiomyomatosis (LAM)(2). Although symptoms like hematuria or flank pain may occur, they are more frequently detected incidentally during imaging for unrelated reasons.

These hormone-sensitive tumors (estrogen, progesterone) may rupture during pregnancy due to elevated levels of estrogen and progesterone; most of the cases in the literature ruptured during pregnancy. We present a patient who was pregnant whose renal mass was diagnosed during pregnancy. The patient was managed conservatively in the antenatal period without any complication, and then given definitive treatment after the birth. We reviewed the literature about cases of RA that have been managed during pregnancy.

\section{Case Report}

A primigravida women aged 26 years was referred to our clinic during her 34th week of gestation with left flank pain. Her medical history was not significant for any disease. The patient had no costovertebral angle tenderness on either side. Her urine analysis revealed pyuria but not hematuria. A urinary tract infection was treated with oral ampicillin. The patient's vital signs were stable and there was no fever. Fetal biometric measures were compatible with 34 weeks and the amniotic fluid index was normal on ultrasound evaluation. A urinary system ultrasound revealed a 9.9x5.8-cm hypoechoic solid lesion on the left kidney that had distorted the renal calices. Magnetic resonance imaging (MRI) results showed a lobulated, heterogeneously contrasted $11 \times 6.5 \times 5.5-\mathrm{cm}$ soft tissue mass 
lesion arising from the middle segment of the left kidney that contained necrotic areas (Figure 1). Renal function tests were within the normal range. The patient delivered vaginally after cervical ripening with dinoprostone and induction with 4 oxytocine, consecutively, at 36 weeks of gestation due to the patient's anxiety about the risk of tumor rupture. The neonate was a $2430 \mathrm{~g}$ girl with 1st/5th min Apgar scores $9 / 10$, respectively. The neonate was discharged without any problems. Two weeks after the delivery, the patient underwent laparoscopic a radical left nephrectomy. Pathologic evaluation of the specimen showed epitheloid angiomyolipoma with intact tumor-free borders around the mass (Figure 2). After being discharged from hospital, the patient had no complaints in the third month after the operation. The patient had normal neurologic, pulmonary, and skin examination, by which we excluded TSC and LAM.

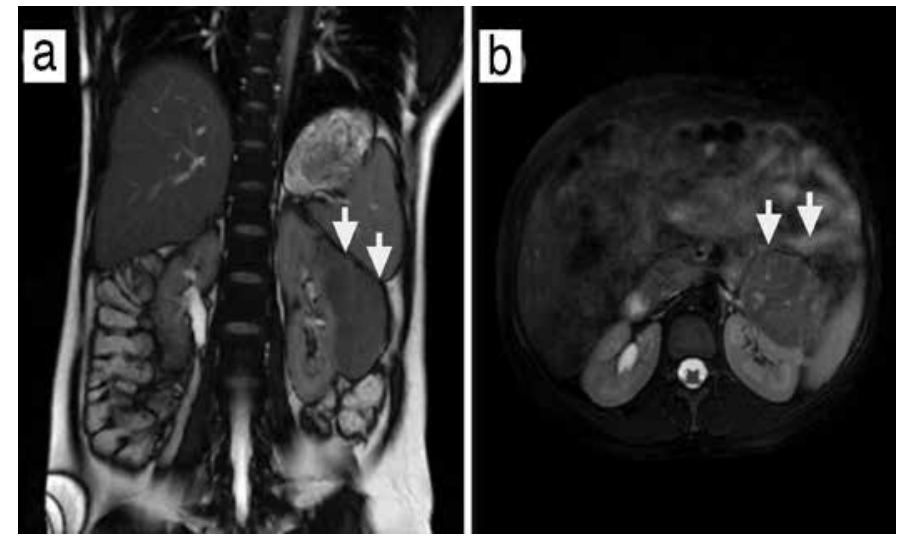

Figure 1. Magnetic resonance imaging of the renal tumor a) coronal section, b) axial section (arrow indicating the tumor)
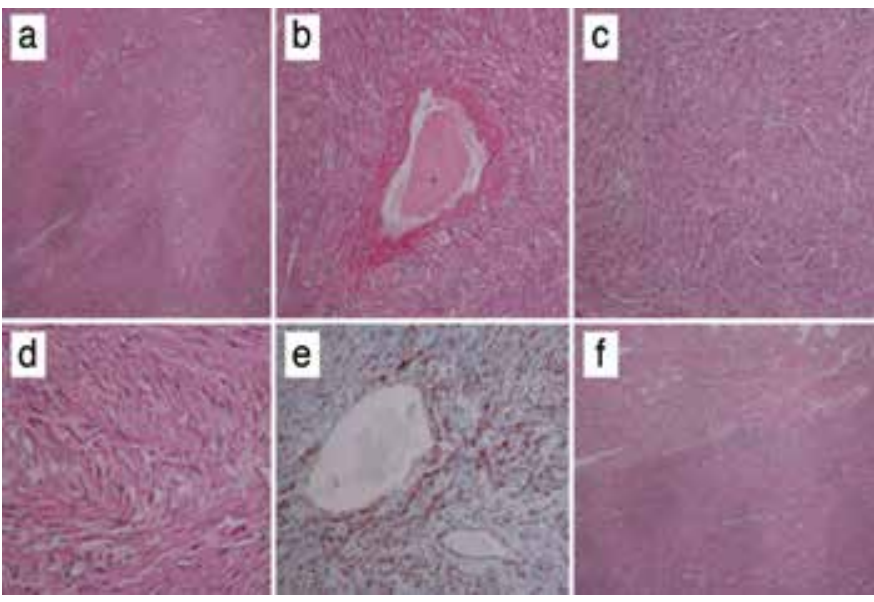

Figure 2. a) Hematoxylin\&Eosin stain under x40 magnification, spindle cells in fascicular pattern, starting from the perivascular area, b) x100 magnification, c) x200 magnification, smooth muscle cells component, d) x400 magnification, e) x100 magnification, HMB-45 positivity in immunohistochemistry, f) x40 magnification, tumor area in the upper part, normal renal tissue below

\section{Discussion}

More than 25\% of RA's carry estrogen and progesterone receptors like in pulmonary $\operatorname{LAM}^{(3,4)}$. Therefore, they are thought to grow during pregnancy or with oral contraceptive use. Symptoms may occur during these periods in previously asymptomatic patients. There are few case reports about RA's during pregnancy in the literature and these are summarized in Table 1.

Although most angiomyolipomas are located in the kidneys, they can also be diagnosed in other organs like liver, spleen or uterus as they arise from epitheloid cells around blood vessels(5). Some cases can present with sudden abdominal or flank pain and with symptoms of hypovolemic shock, which suggests rupture of the tumor into the retroperitoneal area; however, they are frequently asymptomatic. In cases of rupture, hemodynamic stability is of critical importance regarding the selection of optimal treatment strategy. For hemodynamically unstable patients, emergency surgery or arterial embolization (if available) are the main options of treatment. For asymptomatic patients, a conservative approach may be chosen, especially during pregnancy ${ }^{(5)}$. For these patients, definitive treatment may be postponed until the postpartum period(6). Similarly, we delayed the definitive treatment of the tumor to the postpartum period. However, there is as yet no consensus in the literature as to how long the conservative approach is suitable. Close follow-up of patients who are pregnant may be preferred because of the high risk of rupture.

Most of the cases during pregnancy reported in the literature ruptured during pregnancy $(21 / 26,81 \%)$. To the best of our knowledge, only four (15\%) of the 26 cases reported (including ours) have not ruptured during pregnancy (Table 1 ). These were managed with nephrectomy during or after pregnancy $(7-9)$.

The mean age and mean gestational age of the patients in the literature at the time of diagnosis was 31.4 years and 27.7 weeks, respectively. Twenty-one of these cases (81\%) ruptured (Table 1). The average size of the tumors measured with ultrasound or MRI was $10.1 \mathrm{~cm}$ and tumor size did not correlate with the risk of rupture. The tumor in our case was $11 \mathrm{~cm}$ and rupture did not occur tumor, whereas in dos Santos et al.'s case, rupture was reported with a tumor that measured $5 \mathrm{~cm}^{(11)}$. Therefore, estimation of the risk of rupture using only tumor size would not be accurate.

Most patients with RA in the literature delivered their babies via cesarean section $(15 / 26,56 \%)$, whereas only $5(19 \%)$ were delivered vaginally (Table 1). However, vaginal delivery can be considered as a safe approach for these patients. Mode of delivery for these patients should be decided based on obstetric indications, because cesarean section does not reduce the risk of rupture. Vacuum extraction can also be an alternative option for these patients in order to shorten the second stage of the labor. In our case, we did not need vacuum extraction due to precipitous labor.

Current treatment options for RA include partial/total nephrectomy (open or laparoscopic), cryoablation, radiofrequency ablation, or 
arterial embolization(3). Fourteen (54\%) of the patients reported in the literature needed nephrectomy, whereas $12(46 \%)$ were treated conservatively with or without arterial embolization (Table 1). Embolization can also be performed after 12 weeks of gestation with minimal fetal radiation exposure(3). This can be performed using devices such as coils, gelfoam, or polyvinylalcohol(3). The main complications of embolization are Post-embolization syndrome (POS) (inflammation, fever, leukocytosis, and flank pain) and liquefactive necrosis(3). POS generally resolves spontaneously, whereas percutaneous drainage might be needed for liquefactive necrosis(3). In contrast to embolization or ablation, surgery has the important advantage of allowing for pathologic evaluation for a definitive diagnosis. Differential diagnosis of these lesions includes renal cell carcinoma, oncocytoma, and metastatic lesions from primary tumors elsewhere. Radiographic features can usually distinguish these from each other. For those patients in whom radiographic evaluation is not enough for definitive diagnosis as in our case, either biopsy or nephrectomy (as a definitive treatment) can be performed.

In conclusion, renal angiomyolipomas are rare tumors but physicians who encounter renal masses during pregnancy should keep these in mind, because they can grow and be symptomatic for the first time during pregnancy. MRI is usually enough for diagnosis, but for uncertain cases, biopsy or surgery can be performed. Treatment strategies should be individualized due to insufficient data in the literature to support any one in particular.

Table 1. Literature review of renal angiomyolipoma cases during pregnancy

\begin{tabular}{|c|c|c|c|c|c|c|}
\hline Reference (Year) & $\begin{array}{l}\text { Age } \\
\text { (years) }\end{array}$ & $\begin{array}{l}\text { Gestational } \\
\text { week }\end{array}$ & $\begin{array}{l}\text { Largest } \\
\text { Tumor } \\
\text { size }(\mathrm{cm})\end{array}$ & Rupture & RA management & $\begin{array}{l}\text { Pregnancy } \\
\text { management }\end{array}$ \\
\hline Bidault $(2015)^{(9)}$ & 31 & NR & 9 & No & Nephrectomy & \\
\hline Preece $(2015)(10)$ & 45 & 24 & 15 & Yes & Embolization+Nephrectomy & Term C/S \\
\hline Davis (2013)(12) & NR & NR & NR & NR & NR & NR \\
\hline Pontis $(2013)(13)$ & 33 & 34 & 4.8 & Yes & Nephrectomy & Preterm C/S \\
\hline Iruloh (2013)(14) & 23 & 31 & 12 & Yes & Embolization+Nephrectomy & Term C/S \\
\hline Ferianec $(2013)^{(15)}$ & 30 & 9 & 21 & Yes & Nephrectomy & Therapeutic abortion \\
\hline Lopater J (2011)(8) & 34 & 30 & 4 & No & Nephrectomy & Term C/S \\
\hline Gyimadu $(2011)^{(17)}$ & 21 & 25 & 11.5 & Yes & Conservative+Later Embolization & Term C/S \\
\hline Zapardiel (2011)(18) & 30 & 35 & 11 & Yes & Embolization & Preterm C/S \\
\hline Komeya (2010)(19) & 39 & 38 & 8 & Yes & Embolization & Term C/S \\
\hline Binkowska (2009)(20) & 26 & 20 & 17,4 & Yes & Embolization & Term C/S \\
\hline Kontos $(2008)(21)$ & 28 & 33 & 7 & Yes & Nephrectomy & Preterm C/S \\
\hline Illescas Molina (2007)(5) & 36 & 28 & NR & Yes & Conservative & Term C/S \\
\hline Koh $(2007)^{(22)}$ & 31 & 12 & NR & Yes & Nephrectomy & Term C/S \\
\hline Oka (1999)(25) & 32 & 36 & NR & Yes & Nephrectomy & Term C/S \\
\hline Yanai (1996)(26) & NR & 39 & NR & Yes & Embolization & Term Delivery \\
\hline Lee $(1994)(27)$ & 29 & 27 & NR & Yes & Nephrectomy & Fetal death \\
\hline
\end{tabular}


More experience with these strategies is needed before an optimal treatment method can be recommended. It is our hope that the distinctive features of our case will further enhance the knowledge of the management of these rare tumors during pregnancy.

Informed Consent: It was taken.

Concept: Cihan Çetin

Design: Cihan Çetin, Selim Büyükkurt

Data Collection or Processing: Cihan Çetin, Cüneyt Evrüke

Analysis or Interpretation: Cihan Çetin, Cineyt Evrüke, Cansun Demir

Literature Search: Cihan Çetin, Selim Büyükkurt

Writing: Cihan Çetin, Selim Büyükkurt, Cansun Demir, Cüneyt Evrüke

Peer-review: External and Internal peer-reviewed.

Conflict of Interest: No conflict of interest was declared by the authors.

Financial Disclosure: The authors declared that this study has received no financial support.

\section{References}

1. Gimeno Argente V, Bosquet Sanz M, Bonillo Garcia MA, Gomez Perez L, Pontones Moreno JL, Jimenez Cruz JF. Conservative surgery of bilateral renal angiomyolipoma during pregnancy. Actas Urol Esp 2006;30:633-7.

2. Martignoni G, Pea M, Reghellin D, Zamboni G, Bonetti F. PEComas: The past, the present and the future. Virchows Arch 2008;452:119-32.

3. Morales JP, Georganas M, Khan MS, Dasgupta P, Reidy JF. Embolization of a bleeding renal angiomyolipoma in pregnancy: Case report and review. Cardiovasc Intervent Radiol 2005;28:265-8.

4. Ohori NP, Yousem SA, Sonmez-Alpan E, Colby TV. Estrogen and progesterone receptors in lymphangioleiomyomatosis, epithelioid hemangioendothelioma, and sclerosing hemangioma of the lung. Am J Clin Pathol 1991;96:529-35.

5. Illescas Molina T, Montalvo Montes J, Contreras Cecilia E, Munoz Muniz Mdel M, Gonzalez Gonzalez A, Herraiz Martinez MA. Angiomyolipomas, tuberous sclerosis and pregnancy. Ginecol Obstet Mex 2009;77:380-6.

6. Tanaka M, Kyo S, Inoue M, Kojima T. Conservative management and vaginal delivery following ruptured renal angiomyolipoma. Obstet Gynecol 2001;98:932-3.

7. Govednik-Horny C, Atkins M. Angiomyolipoma with vascular invasion during pregnancy. Ann Vasc Surg 2011;25:1138.

8. Lopater J, Hartung O, Bretelle F, Bastide C. Management of angiomyolipoma vena cava thrombus during pregnancy. Obstet Gynecol 2011;117:440-3.

9. Bidault V, Pignot G, Rocher L, Glas L, Patard JJ. Renal angiomyolipoma with inferior vena cava thrombosis during pregnancy. Prog Urol 2015;25:288-92.

10. Preece P, Mees B, Norris B, Christie M, Wagner T, Dundee P. Surgical management of haemorrhaging renal angiomyolipoma in pregnancy. Int J Surg Case Rep 2015;7:89-92
11. dos Santos MM, Proenca SM, Reis MI, Viana RM, Martins LM, Colaço JM, Nunes FM. Spontaneous rupture of renal angiomyolipoma during pregnancy. Rev Bras Ginecol Obstet 2014;36:377-380.

12. Davis NF, Kelly R, Lee MJ, Mohan P. Selective arterial embolisation of bilateral angiomyolipomata in a symptomatic pregnant female. BMJ Case Rep 2013;2013.

13. Pontis A, Piras B, Meloni A, De Lisa A, Melis GB, Angioni S. Rupture of renal angiomyolipoma in pregnancy. J Obstet Gynaecol 2013;33:628-9.

14. Iruloh C, Keriakos R, Smith DJ, Cleveland T. Renal angiomyolipoma and lymphangioleiomyomatosis in pregnancy. J Obstet Gynaecol 2013;33:542-6.

15. Ferianec V, Gabor M, Cano M, Papcun P, Holoman K. Severe retroperitoneal haemorrhage in the first trimester of a multiple pregnancy after spontaneous rupture of renal angiomyolipoma. Arch Gynecol Obstet 2013;288:1193-4.

16. Bolufer E, Lopez-Fontana G, Castillo OA. Robot assisted partial nephrectomy (Da Vinci) in an angiomyolipoma associated to Wünderlich Syndrome. Arch Esp Urol 2012;65:831-4.

17. Gyimadu AO, Kara O, Basaran D, Esinler I. Conservative management of a retroperitoneal hemorrhage following a ruptured renal angiomyolipoma in pregnancy. J Obstet Gynaecol Res 2011;37:1569.

18. Zapardiel I, Delafuente-Valero J, Bajo-Arenas JM. Renal angiomyolipoma during pregnancy: review of the literature. Gynecol Obstet Invest 2011;72:217-9.

19. Komeya M, Matsumoto T, Fujinami K, Senga Y, Asakura T, Goto A. Rupture of renal angiomyolipoma during pregnancy: A case report. Hinyokika Kiyo 2010;56:261-4.

20. Binkowska M, Debska M, Mazurek M, Slapa R, Debski R. Embolization of renal angiomyolipoma in pregnancy: case report. Ginekol Pol 2009;80:449-52.

21. Kontos S, Politis V, Fokitis I, Lefakis G, Koritsiadis G, Simaioforidis $\mathrm{V}$, et al. Rupture of renal angiomyolipoma during pregnancy: a case report. Cases J 2008;1:245.

22. Koh JL, Lee YH, Kang CY, Lin CN. Simultaneous cesarean section and radical nephrectomy for angiomyolipoma with spontaneous bleeding during pregnancy: a case report. J Reprod Med 2007;52:338-40.

23. Storm DW, Mowad JJ. Conservative management of a bleeding renal angiomyolipoma in pregnancy. Obstet Gynecol 2006;107:490-2.

24. Raft J, Lalot JM, Meistelman C, Longrois D. Influence of pregnancy on renal angiomyolipoma. Gynecol Obstet Fertil 2005;33:898-906.

25. Oka D, Mizutani S, Takao T, Inoue H, Nishimura K, Miyoshi S. Spontaneous rupture of a renal angiomyolipoma in pregnancy: a case report. Hinyokika Kiyo 1999;45:423-5.

26. Yanai H, Sasagawa I, Kubota Y, Ishigooka M, Hashimoto T, Kaneko $\mathrm{H}$, et al. Spontaneous hemorrhage during pregnancy secondary to renal angiomyolipoma. Urol Int 1996;56:188-91.

27. Lee JD, Chang HC, Chu SH, Hsueh S, Soong YK. Massive retroperitoneal hemorrhage from spontaneous rupture of a renal angiomyolipoma during pregnancy. A case report. J Reprod Med 1994;39:477-80 